\title{
Sustainability of Touristic Potential of the Old Van City and Castle of Van in Terms of Cultural, Historical and Natural Values
}

\author{
Ayşe Sirel ${ }^{1}$ and Osman Ümit Sirel ${ }^{2}$ \\ 1. Faculty of Architecture and Design, Istanbul Aydin University, Istanbul 34295, Turkey \\ 2. Faculty of Architecture and Design, Bahçeşehir University, Istanbul 34353, Turkey
}

\begin{abstract}
Tourism has become the world's fastest growing sector due to acceleration of technology and information flow in the globalized world of today, development of the modern mass transport system and increase in people's disposable income. Upon tourism's being considered as a serious development strategy in the developments of the countries, all the countries of the world have begun to accelerate their investments in this area through utilizing the natural and cultural assets of their countries (heritage) with a view to provide revenue to their economy as well as creation of jobs. This situation, which has emerged as a result of the globalization of supply and demand in tourism, has created certain problems in terms of environmental balance and the living conditions of local people as a result of poor management of the utilization of natural and cultural resources. The objective of this paper is to examine the concepts and principles germane to sustainable tourism which has significant contribution to the development of the countries, made at the macro level both in the world and in Turkey. The aim of this paper, at the micro level, is to create awareness incident to the tourism resources of the Van Region and the Old Van province and ensure the utilization of these resources through protection thereof. At the end of the study, the importance of the protection of heritage resources as well as fair use thereof in terms of increasing the competitiveness of Turkey on a global scale in tourism is addressed in the light of the overall evaluations.
\end{abstract}

Key words: Sustainability, sustainable tourism, archeological site area, natural site area, Urartian civilization.

\section{Introduction}

Tourism is defined as temporary, short-term movements, travels of people to places, by leaving the places normally they live and work and their activities in these places while they stay there [1-3]. Tourism has become the world's fastest growing sector due to acceleration of technology and information flow in the globalized world of today, development of the modern mass transport system and increase in people's disposable income. The number of 25 million tourists in 1950 that has reached 278 million in 1980 and 1,035 million in 2012, and will reach 1.6 billion in 2020 and 1.8 billion in 2030 according to the vision report issued by WTO (World Tourism Organization) which has the

Corresponding author: Ayșe Sirel, Ph.D., assistant professor, research fields: urban design and architectural design. E-mail: aysesirel@yahoo.com.tr. most extensive network of tourism-related activities and is the largest international specialized agency of the world. In the same report of the World Tourism, it is mentioned that tourism revenue across the globe that has reached $\$ 262$ billion in 1990, \$475 billion in 2000 and $\$ 1$ trillion in 2012, is expected to be $\$ 2$ trillion in 2012 [4-6].

Upon tourism's being considered as a serious development strategy in the developments of the countries, all the countries of the world have begun to accelerate their investments in this area through utilizing the natural and cultural assets of their countries (heritage) with a view to provide revenue to their economy as well as creation of jobs [7]. Policies and actions that ignore environmental concerns and based on only economic development have led to short-term improvement in the countries. However, the 
long term poor management of the use of natural and cultural resources has led to some problems in the environmental balance and the local people's living conditions [8]. This situation, which has emerged as a result of the globalization of supply and demand in tourism, has created a need to reconsider the structuring processes of tourism which plays an important role in growth in many countries. The change and transformation process experienced in the tourism sector has drawn attention to the economic, social, cultural and environmental impacts caused by the sector. In this study, the environmental impacts are studied in parallel with the subject of the content.

In our day, a sustainable development concept has gained importance in which all the resources in the environment with which the people interact are protected and managed while economic, social and cultural needs of the people and tourists who visit the region are met. This is simply because the pristine surroundings pave the way to emergence and development of the tourism sector. As such, the traditional approach of tourism activities which has focused on economic production dimension has been replaced by modern and environment friendly approaches that do not destroy the nature, protect the natural environment and respect the culture and lifestyle of the local people. Sustainable tourism policies, strategies and action plans that can meet the same needs of the next generations have begun to be formed when development plans and programs are prepared for the tourism zones in form environmentally $[9,10]$.

\section{Methodology}

In this study, the bearing capacities of the areas subject to tourism are taken into account and the importance and the need for a planning approach which maximizes environmental and social benefits in addition to the economic benefits is demonstrated. In this context, literature researches are the "sustainability" and "sustainable tourism" concepts which were conducted firstly. The economic situation created by the spread of mass tourism in the world as from the 1960s, the rapid growth of the global environment and devastating impacts thereof on environmental values is explained. The rapid growth in the tourism sector and the "Sustainability of Tourism" concept which has become a current issue in 1990s has been studied. The importance of implementation of a range of plans and applications from local action plans to regional plans is emphasized for the development of tourism in a stable way and in line with the principles of sustainability. In this context, competitiveness on a global scale of Turkey which has begun to enter the tourism industry on a global scale from the 1980s has been indicated basing on the "Travel and Tourism Competitiveness Report-2013" prepared by the WEF (World Economic Forum). Evaluations have been made as to issues regarding use of tourism resources in the tourism sector which is important for the Turkish economy also like many countries of the world as well as the status thereof in national and international scales.

SWOT (strengths, weakness, opportunities, threats) analysis has been conducted as to the current status and the likely future status of the tourism potential for the sampling area (case study) of the study. "The Old Van City and Castle of Van" and the Van Region in which the foregoing are located. As a result of the analysis carried out issues as to use of the heritage resources (natural and cultural) subject to tourism in the Van Region have been identified. The final evaluation includes recommendations as to sustainability of values providing tourist attraction regarding both "Van Region" and "the Old City of Van".

\section{New Dimension of Tourism: Sustainable Tourism}

\subsection{Sustainability Concept (Background of Sustainability and Sustainable Development)}

The concept of sustainability is one of the most discussed topics in the world in our day. The concept 
which has emerged as a necessity of social life manifests itself in different sizes.

"Macmillan Dictionary of the Environment" defines the concept of sustainability as "economic growth which continues constantly based on the depletion of renewable resources and which has a limited destruction to the environment". According to Ruckelshaus [11], sustainability is the idea that economic growth and development can be provided by mutual interaction within the largest limits of ecology and protected in time. Sustainability, according to Gilman [12], is the functioning ability of a community, ecosystem or any ongoing system without depleting the main resources thereof for an indefinite time in the future.

Much as it has been found in the literature scanning that different expressions are utilized regarding the definition of sustainability, it is seen in almost all definitions that there are three common dimensions. These are the dimensions of socio-cultural sustainability, environmental sustainability and economic sustainability (Fig. 1) [13, 14]. Social sustainability is based on the understanding of providing intergenerational stability and bequeathing natural, cultural and all other sources required for protecting the right of life of future generations. Environmental sustainability is related to protection of the power of defense of ecological balances against harmful effects and adaptation thereof. Economic sustainability is related to realization of the development goals incident to increasing the level of prosperity of human life. Much as achieving these three dimensions in all circumstances is difficult, the main purpose is to determine the balances and priorities [15].

\subsection{Concept of Sustainable Tourism}

Tourism is based on the presence of heritage resources which are collected in three groups. These are [16]:

- natural environmental resources: nature, landscape, environment of natural life and wild life;

- built environmental resources: architecture, archeology and monumental structures;

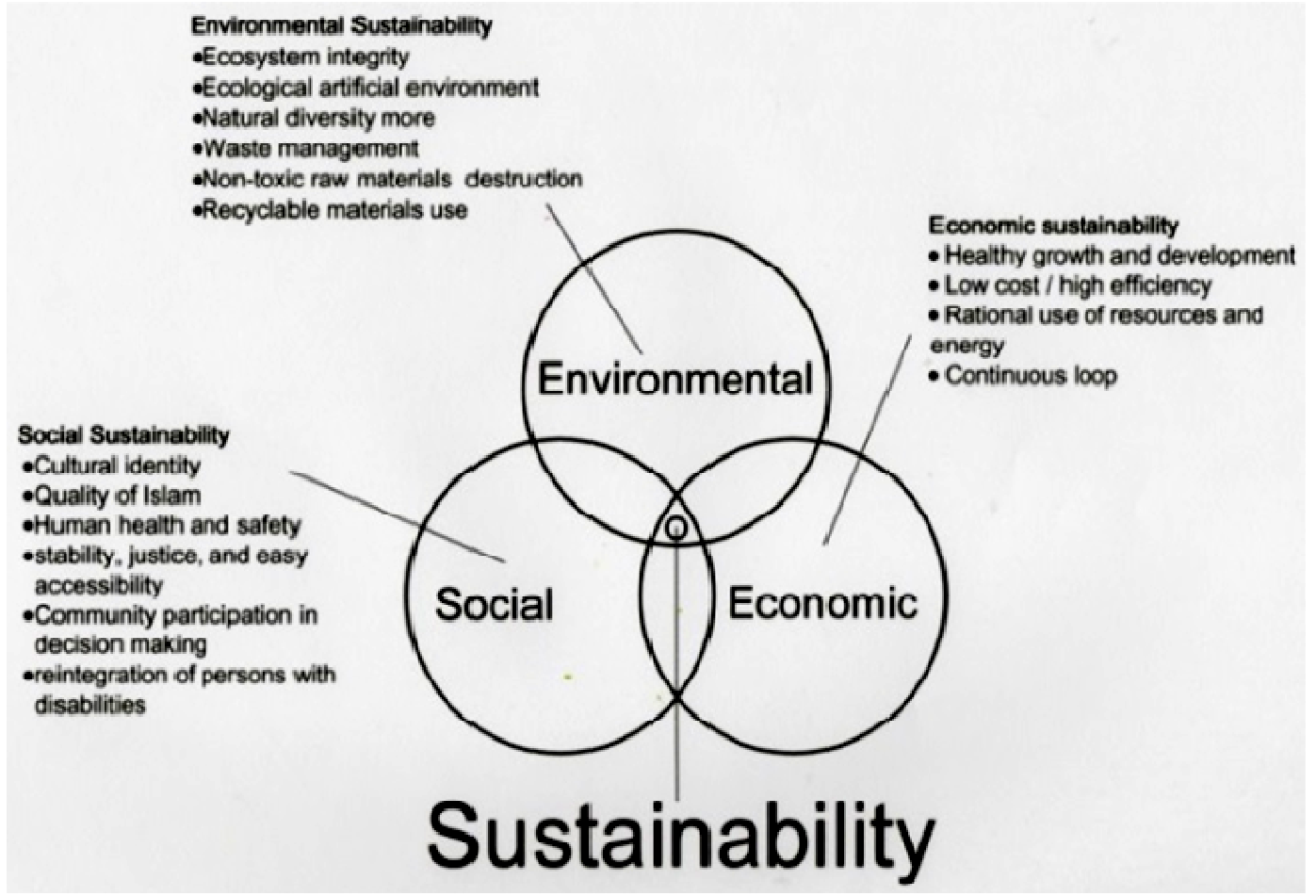

Fig. 1 The "three dimensions" of sustainability [13, 14]. 
- cultural environmental resources: culture, language and local identity.

Tourism sector based on the interaction between the above-mentioned sources (heritage) and the human actions is one of the areas affected by sustainable approaches. Growth of mass tourism all over the world as from the 1960s and the rapid enlargement of destination environment have created a very critical and important problem in terms of environment $[17,18]$. Due care has not been given to natural and cultural imbalances and protection-use issues in countries placing emphasis on mass tourism and tourism has made devastating effects on the environmental values between the years of 1960 and $1980[7,19]$. However, the rapid growth in the tourism sector has also led to a more sustainable tourism demand [20] and the concept of "tourism sustainability" has emerged. The "Sustainability of Tourism" concept which has acquired currency in 1990s has entered to the agenda of the world public opinion with the report titled “Our Common Future” (known as the Brundtland Report) prepared by the World Environment and Development Commission in 1987 [21]. In the report, it has been emphasized to establish a vital bridge between the conflicting concepts of economic growth and environmental protection for the "first time" and the importance of "sustainability" of the development [10, 22].

In our day, the subject of sustainable tourism has become an important area of research all over the world. In the researches made in the last 20 years, several definitions have been made related to sustainable tourism. However, there is not still a generally accepted definition. Sustainability is the idea of associating all kinds of tourism with environment. But the problem is incident to how and by which policies to use the concept in a practical and useful way [20]. Müller [23] states that sustainable tourism is closely related to qualitative growth and defines quality of growth as increase in quality of life. Müller [23] explains this definition magic pentagon is named as the schematic diagram, too. These five factors that are made up of economic health, well-being of the local population, protection of the natural resources, cultural development and the satisfaction of the visitors/tourists, represent sustainable tourism if they are balanced without being dominant on each other. Saarinen [15] defines sustainable tourism as the usage made without giving harm to resources, society, economy, culture and environment of any place. In a study prepared jointly by the United Nations Environment Program and the United Nations Tourism Organization, sustainable tourism is defined as meeting the needs of tourists and hosts within the tourism by increasing and preserving the value of the existing resources in our day also in the future [2].

The common points of the above-mentioned various definitions as to sustainable tourism are use and management of heritage resources by protecting them for sustainability of ecological processes, biological diversity and life support systems [24]. Tourism industry's existence and sustainability must be based on use of heritage resources by ensuring socio-cultural and environmental sustainability thereof rather than considering only economic sustainability maximizing the profit [25]. The heritage resources create a base for the growth of tourism while providing a power for the protection of heritage tourism thanks to the funds created thereby. Tourism will lose its meaning without the existence of heritage. Tourism will lose its growth potential without sustainable tourism management [26].

\subsection{Objectives of Sustainable Tourism}

The main objective of sustainable tourism is to protect the values that constitute resources for tourism and develop tourism in the way that it will constantly contribute to the local economy and social life. The sub-objectives of sustainable tourism within this main objective can be summarized as follows [26, 27]:

- to protect the historical, natural and cultural values (inheritance); 
- to make tourism gain from historical, natural and cultural values;

- to develop investment opportunities in the tourism sector;

- to increase the tourism revenues (by increasing the number of domestic-foreign tourists and by increasing the number and quality of beds and other services to this end);

- to diversify and increase the types of tourism and thus spread it to four seasons;

- to improve and ease means of transport;

- to solve problems regarding service and infrastructure;

- to increase the quality and quantity of tourism sector in terms of manpower;

- to increase tourism-oriented promotion and marketing activities.

\subsection{Principles of Sustainable Tourism}

Some basic principles must be observed to achieve sustainable tourism activities successfully from the local scale to global scale. These are [28-30]:

- Tourism's natural, historic and cultural resources must be protected for the continuity of its benefits to the current society also in the future;

- The development of tourism must be planned and managed in a way that it will not lead to environmental and socio-cultural issues in the area where tourism activities are performed;

- Environmental quality should be maintained and developed in accordance with the requirements in the area where tourism activities are performed;

- Tourist satisfaction must be provided in a high rate in order to maintain the marketability and popularity of the area where tourism activities are performed in the future;

- The benefits obtained from tourism must be spread to large segments of society;

- The participation of local people in decision-making should be ensured while local economies are supported.
As a conclusion, we can say that researches and applications implemented in the last 20 years regarding the effective implementation of principles and objectives of sustainable tourism in tourism planning show that there are still problems in the implementation of sustainable tourism. It is an inevitable fact that the bearing capacity of the areas where tourism activities are performed must be taken into account and the framework of a planning approach that maximizes environmental and social benefits and that minimizes the negative effects must be redrawn [31, 32]. The requirements as well as rights and responsibilities of different stakeholders in tourism(national government, local authorities, tourism organizations, local people, tourists, etc.) should be considered regarding this issue [33]. If policies as to environmental protection and humane living conditions as well as necessary funding are not created it does not seem possible to ensure the maintenance of sustainable tourism. Sustainability is necessary for the successful future of tourism itself [34]. What needs to be done to this end is as follows [7].

Action issues:

- establishment of a national tourism strategy that is updated periodically and master plan for tourism development and management;

- development of coherent policy to reflect tourism's challenges;

- work with the tourism industry to learn about the realities shaping available choices, while helping create an environment in which higher standards can be delivered;

- integration of conservation of environmental and biodiversity resources into all strategies and plans;

- enhancement prospects of economic development and employment while maintaining protection of the environment sustainability in tourism and related activities;

- strengthening of the coordination of tourism policy, planning development and management at both national and local levels. 


\section{Sustainable Tourism in Turkey}

Turkey is a country located at the crossroads of three continents; on the corridor of highway, rail and maritime transportation with historical, geographical, and strategic importance. Turkey has hosted many civilizations and it can be called as an open-air museum. Turkey's tourism potential is evaluated thanks to its natural, cultural and historical assets. Like many countries of the world, tourism leads to gaining foreign currency in Turkey due to its importance in terms of bringing revenues and increasing employment (by opening work areas).

Tourism in Turkey has been considered as an economic sector by virtue of the development plans implemented in the 1960s and has been improved with regulations to that effect. Tourism industry has begun on a global scale by the new regulations and incentives implemented as from the 1980s. Tourism in Turkey has achieved a major pace of development by the Tourism Incentive Law No. 2634 enacted in 1982. However, the increase in tourism demand to Turkey-marketed as cheap vacation paradise, in line with the applied mass tourism-has been evaluated as a success and investments as to resorts and coastal hotel have been supported in an unplanned way with the incentives provided. As a result of allocation of forest areas that are public land to tourism investors, uncontrolled buildings have been made which have caused a variety of environmental issues [35]. On the other hand, the leading countries of the world tourism have put into action a range of plans from local action in regional plans and national strategic plans and strived to manage tourism in a stable way and within sustainability principles [36]. In as much as this rapid development process in tourism Turkey has not been managed by qualified policies and plans, the intensity of use (capacity) on heritage resources mentioned hereinabove have increased. Sure enough it has been stated in the "Sustainable Tourism" report prepared by the Turkish Industrialists' and Businessmen's Association in 2012 that tourism is one of the most affected sectors in the medium and long term and due to depletion of natural resources as a result of overuse [37].

WEF has published "The Travel and Tourism Competitiveness Index 2013” of 140 countries which Turkey is also included [38]. WEF has published the results of Global Competitiveness Index adapted to tourism sector under the name of "The Travel and Tourism Competitiveness Report 2013” [5]. The Travel and Tourism Competitiveness Index 2013 aimed at measuring the development and competitiveness of the tourism sector in countries of the world consists of 14 regulatory titles. The cited 14 titles are arranged in three sections according to their subjects.

Place of Turkey has been given in Table 1 regarding the cited 14 regulatory titles in the Travel and Tourism Competitiveness Report. The average of the three sub-headings is given in Table 2 [39, 40]. Much as Turkey's among the top ten countries in terms of attracting visitors mostly, it is in the 46th place in the competitiveness index which means that the current tourism policies have to be developed on the basis of

Table 1 Turkey’s T\&T (Travel and Tourism) Competitiveness Index rankings in 2013 (compiled from the Travel and Tourism Competitiveness Report 2013).

\begin{tabular}{llllll}
\hline Pillars & Rank & Rank & Rank \\
\hline T\&T regulatory framework & 64 & $\begin{array}{l}\text { Business environment } \\
\text { and infrastructure }\end{array}$ & 52 & $\begin{array}{l}\text { T\&T human, cultural and natural } \\
\text { resources }\end{array}$ & 27 \\
1. Policy rules and regulations & 34 & 6. Air transport infrastructure & 29 & 11. Human resources & 68 \\
2. Environmental sustainability & 95 & 7. Ground transport infrastructure & 52 & 12. Affinity for travel and tourism & 35 \\
3. Safety and security & 79 & 8. Tourism infrastructure & 45 & 13. Natural resources & 78 \\
4. Health and hygiene & 64 & 9. ICT infrastructure & 71 & 14. Cultural resources & 19 \\
5. Prioritization of travel and tourism & 63 & 10. Price competitiveness & 112 & & \\
\hline
\end{tabular}


Table 2 Turkey's T\&T Competitiveness Overall Index rankings in 2013 (compiled from the Travel and Tourism Competitiveness Report 2013) (Sub-indexes).

\begin{tabular}{ll}
\hline Sub-indexes & Rank \\
\hline T\&T regulatory framework & 64 \\
Business environment & 52 \\
T\&T human, cultural, and natural resources & 27 \\
Overall index & 46 \\
\hline
\end{tabular}

sustainability and there is a need for new, alternative strategies.

As can be understood from the Tables 1 and 2 Turkey's competitiveness on a global scale is based on the nature of the environmental-cultural-economic dimensions which are the basic dimensions of sustainability. For sustainable tourism, it is necessary to establish policies regarding equitable use of heritage resources. In this context, a tourism action plan report was prepared in 2007 by the Ministry of Culture and Tourism with the objective of evaluating Turkey's tourism potential better [41]. It has been identified in Turkey’s Tourism Strategy_2023 Report as the main target to establish the main purpose of tourism development as its being sustainable, proper use of resources and improving the life quality of present and future generations. In line with these objectives, the framework of macro decisions such as especially physical planning, organization models, financing alternatives and legal basis has been drawn. Strategic decisions of Turkey-which has the goal of full membership to European Union-taken in the 2023 Action Plan to be compatible with the "European Union Acquis”, in terms of tourism industry should not be left on paper [42]. The process should be followed up for the success of the strategy and evaluated. Changes should be carried out in accordance with the assessments, if necessary. Governments, public institutions and organizations, planners, the business world, universities and non-governmental organizations have important tasks and responsibilities in our day and in the future. If development of sustainable tourism is desired, qualitative development, continuity and equitable use of resources should be given importance.

\section{Tourism Potential of Van Region and Sustainability}

\subsection{Historical Background}

Van province is located at the eastern end of Turkey in terms of geographical position. It is bordered by Iran to the East, Lake of Van to the west, Agri province to the north and Hakkari province to the south (Fig. 2). Van and its surroundings, which is the largest indoor basin of the Eastern Anatolia Region is fairly convenient for settlement location due to its wetland areas as well as the mountainous geography thereof. Van region, having a convenient topographical structure, geographical location and natural beauty, has a long history dating back to 6th millennium BC $[43,44]$.

The "Old Van City, Van Castle and its surroundings", which has the nature of an open-air museum, has been taken under legal protection under "Act on Protection of Cultural and Natural Heritage Number 2863" by the decision taken by "High Council of Historic Monuments and Antiquities" on June 8, 1979 upon being determined as the 1st, 2nd and 3rd Degree archaeological sites [45]. Later, in 1994 a tender was held by the Ministry of Culture and the "Van Castle and its Environment Protection Zoning Plan” was put into action [46]. The protected area boundaries have been decreased with the decision dated Sep. 19, 2002 of Preservation Board of Diyarbakir's Cultural and Natural Heritage. Stress on the use of these resources has increased by decrease of the protected area boundaries hosting heritage resources subject to tourism. In 2013, a new Protection Zoning Plan has been prepared by the "Taha Orhan Planning” office [47].

\subsection{Assets that Create the Tourism Potential}

Van City is located in the focal point of a region rich in terms of natural, historical and cultural values that has created tourism potential. The city also functions as 


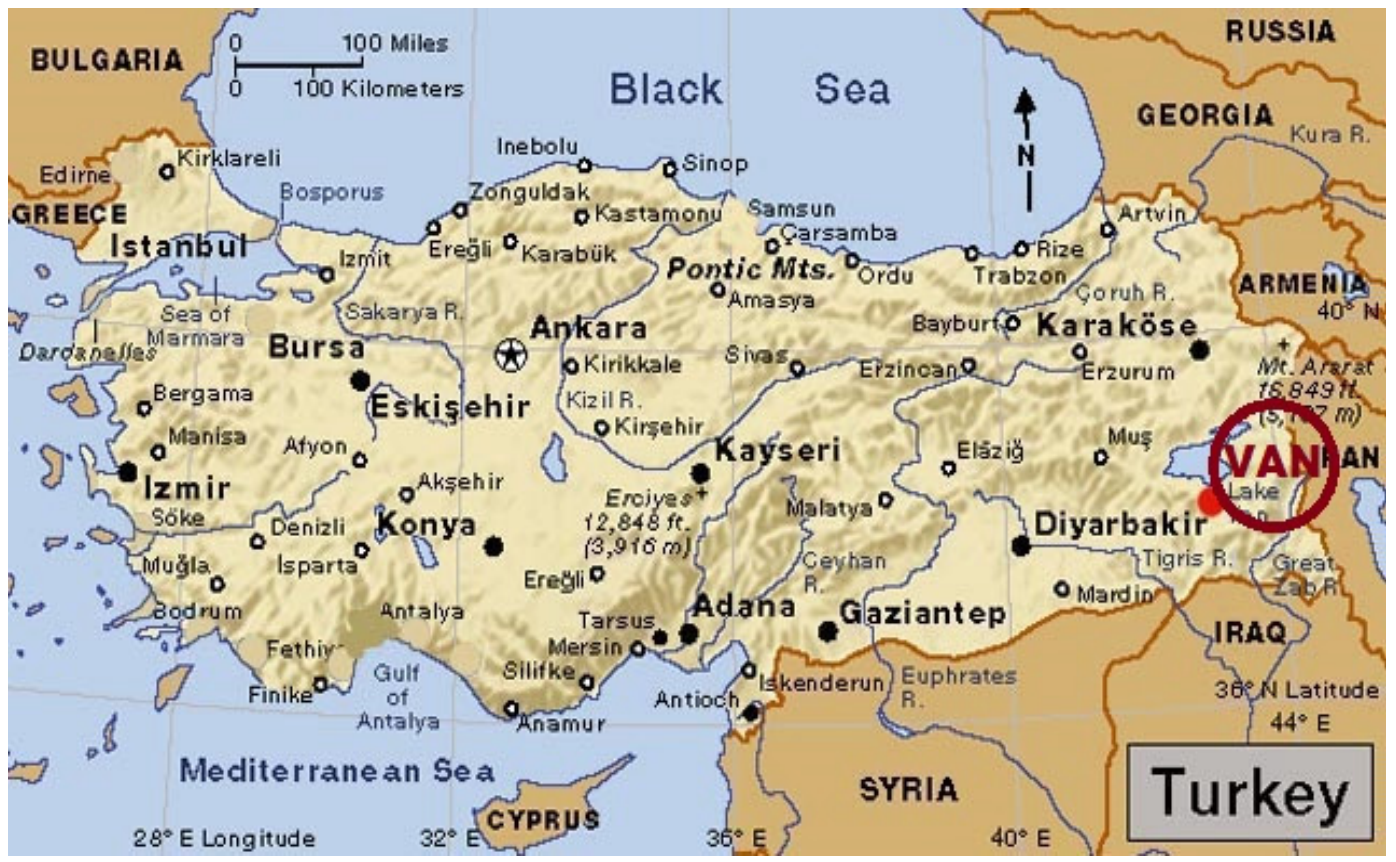

Fig. 2 Location of van.

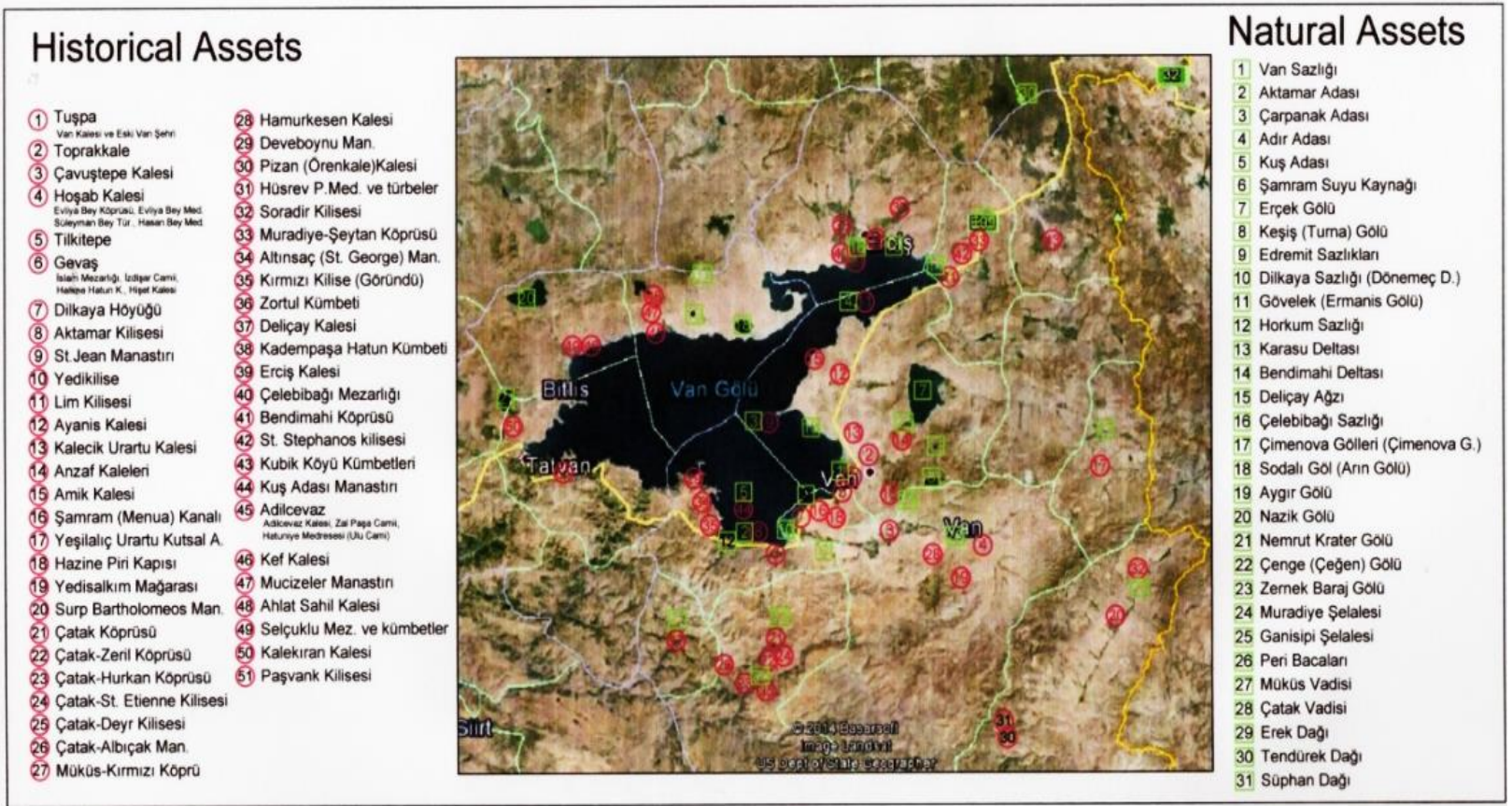

Fig. 3 Historical and natural assets of Van region (O.Ü. Sirel, 2014).

the region's tourism center in terms of tourism and transport infrastructure.

(1) The built environment resources (architecture, archeology, monuments): A portion of the architectural and archaeological assets (heritage) which are the physical heritage of the ancient historical periods have come to our day while a portion thereof have disappeared to a large extent (Fig. 3). The Old Van City, Van Castle and its surroundings which are the most important portions of the heritage values create the sampling area of the study and examined under separate headings; 
(2) Natural environmental sources (nature, landscape, habitat, wildlife): The main natural values (lakes, stream, waterfalls, wetland areas, islands and thermals)which will create tourism potential are as follows [48-50] (Fig. 3);

(3) Cultural environmental resources: Cultures, languages and identity of places: The main cultural values are handicrafts, local music and dances, food culture of the region [51].

\subsection{Evaluation of Assets that Create Tourism Potential within the Context of SWOT Analysis}

SWOT analysis was conducted for the evaluation of the current status and the future potential of the province of Van and its surroundings regarding tourism. It was deemed important to identify strengths and weaknesses in tourism, and determine the opportunities and threats arising from the external environment, in terms of guidance to decision - making process in transition to "sustainable tourism" planning of the province of Van and its surroundings.

\subsubsection{Strengths}

Some strengths are as following: Van Lake's having a rich natural environment; relaxation, recreation and sports facilities offered by Van Lake; Van Lake's having an established history dating back to the 6th millennium BC and its having the material remains of the civilizations living in the area (architectural and archaeological heritage); it is potential to be further enriched in terms of the cited values with researches and excavations to be done; it is advantageous location in terms of transportation in the region (international airport, railway and highway as well as other transportation facilities offered by Van Lake); Existence of the "Yüzüncü Yil University" and educational opportunities provided thereby; opening of educational institutions that will provide qualified labor force for Tourism (Yüzüncü Yil University, Hotel and Tourism Vocational High School, Anatolian Hotel Management and Tourism Vocational High
School); the presence of the young labor force to be employed in the sector; the presence of local handcrafts that has marketing value in terms of tourism; its closeness to Iran, Iraq and Caucasian countries and the possibility of organizing tours including these countries; its rich breakfast and food culture; alternative tourism types developing in the world, including mainly the cultural tourism; possibility of organizing national festivals due to its rich nature and culture.

\subsubsection{Weaknesses}

Some weaknesses are as following: the lack of awareness as to protection of cultural and natural sites in the region; the lack of awareness as to tourism at a sufficient level; the lack of coordination as to the identified tourism-related objectives between the public and private organizations; uneasiness due to political unrest in countries in the region and close countries; the lack of preparation of the framework of a planning approach by taking into consideration the bearing capacities of areas subject to tourism and which maximizes the environmental and social benefits during planning works; all kinds of environmental pollution due to not solving infrastructure problems; the lack of entertainment opportunities tourists will be attractive in terms of lack of; the lack of not keeping a natural, historical and cultural heritage inventory fully and accurately; the lack of realization of a realistic and effective tourism marketing policy; the lack of getting rid of the rural identity in the urban residential texture; the rapid change and extinction of local architectural features; the lack of adequate levels of service quality of businesses that provide tourism service; failure in making tourism sector promotions adequately; the lack of adequate detailed city map and guidelines for tourism purposes; the shortness of appropriate time frames required for the achievement of the tourism objectives (tourism season) compared with the country; shortage of trained workforce for tourism as well as the low level of education of the local people; failure in use of educational opportunities provided by "Yüzüncü Y1l 
University" in an efficient manner (by the public and private agencies).

\subsubsection{Opportunities}

The points are as following: its location on a geography of 2,800 years of civilization inhabited and its possessing heritage assets that can be employed for tourism purposes; its central location in the region, its accessibility and the airport as well as the transport facilities of the lake; Van Castle and other historical places; Van Lake and the coasts.

\subsubsection{Threats}

Threats on the historical values are the following: neglected and unprotected historical areas and buildings; Treasure hunting and vandalism; natural conditions and time-dependent damage; restorations made erroneously and in a hasty manner: the restoration works carried out in the region generally are carried out without sufficient technical and scientific supervisions. Especially, reconstructions conducted without adequate research and in a hasty manner causeless of originality of historical buildings significantly; uncontrolled settlement around the historical heritage assets: Buildings constructed especially in urban centers and neighborhoods without regard to principles of protection may damage historic assets both visually and physically; problems related with archaeological excavations: Not providing enough support usually to the archaeological excavations carried out in the region, their lack of having continuity, not showing sufficient effort in transmission of the architectural remains to the future.

Threats to natural values: Unprotected natural areas that create touristic attraction; pollution: There is an increase in the level of contamination of Van Lake due to the population increase in the settlements around Van Lake and pouring the waste waters to the lake without adequate treatment [52]. There is a significant reduction in the amount of pearl mullet fished on the lake and danger of extinction of this fish which only exists in Van Lake has emerged; failure to comply with hunting prohibition: Much as many areas including
Van reeds are hunting reserves, illegal hunting due to lack of adequate controls in this regard, endanger the existence of many species; changes in the level of Van Lake: Water level of Van Lake can vary significantly over time. Some residential areas are affected by the rising of level of the lake and pouring of the soda lake water to the wetlands next to the shore leads to degradation of the ecological balance [50]; the effects of settlements on the natural values: The natural landscape of Van Lake, which is an attraction on its own, is facing deterioration caused by settlements. There are structures made in some places contrary to the law on the lake shore which can be considered tall for the coast; invasion of second homes (vacation homes) rapidly proliferating in the region the most advantageous coastal areas for tourism in an unplanned manner and without any infrastructure often. These buildings adversely affect the ecological balance in addition to visual and structural problems they cause for the coastal flora and fauna.

\section{The Problematique of Sustainability of Heritage Resources Specific to Van Castle, the Old Van City and Its Surroundings}

The values described in general hereinabove that create tourist attraction for Van region are examined in particular as "Van Castle, the Old Province of Van and Van Lake shoreline in the west" in this section. The area of the study covers Van Castle established in the period of Urartian, the high rocky place which approximately has a height of $80 \mathrm{~m}$ in the plain, the Van Castle Mound in the north and the old province of Van in the south of the castle. The layout of the castle and the old province of Van and the main immovable cultural assets within thereof are shown in Fig. 4.

The reeds in the west between the castle and the lake are important natural assets. This area that is rich in plants and water birds at the same time is the breeding ground of the endangered summer duck in the entire world [48].

The area firstly has been registered as archeological 
site by "High Council of Historic Monuments and Antiquities" with the decision dated June 8, 1976 and number A-1673 and the 1st, 2nd and 3rd degree archeological sites have been determined.

The idea of addressing of these areas within a holistic and comprehensive project has been shared with the science world by Prof. Dr. Taner Tarhan - the Director of the IU/Faculty of Literature/Van Region History and Archaeology Centre, firstly in 1984 in the 2nd Research Results Meeting [43]. In 1986, a file was prepared for the candidature of Van Castle and environs to the "World Heritage List" of UNESCO (United Nations Educational, Scientific and Cultural Organization) [45]. The project could not be realized because it was not supported sufficiently by the relevant organizations and the archaeological excavations started within the project in 1987 were terminated after continuing for a few years.

In 1992, Zoning Plan works began for protection of Van Castle and Environs. The boundaries of the archeological site has been determined again with the decree of Diyarbakir Cultural and Natural Heritage Preservation Board dated Dec. 10, 1993 and number 1405 and the approval of Supreme Council for the Immovable Antiquities and Monuments by extending same and providing a more effective protection [46]. Later the boundaries of the archeological site have been decreased with the decree of Diyarbakir Cultural and Natural Heritage Preservation Board dated Dec. 19, 2002 and number 3053.

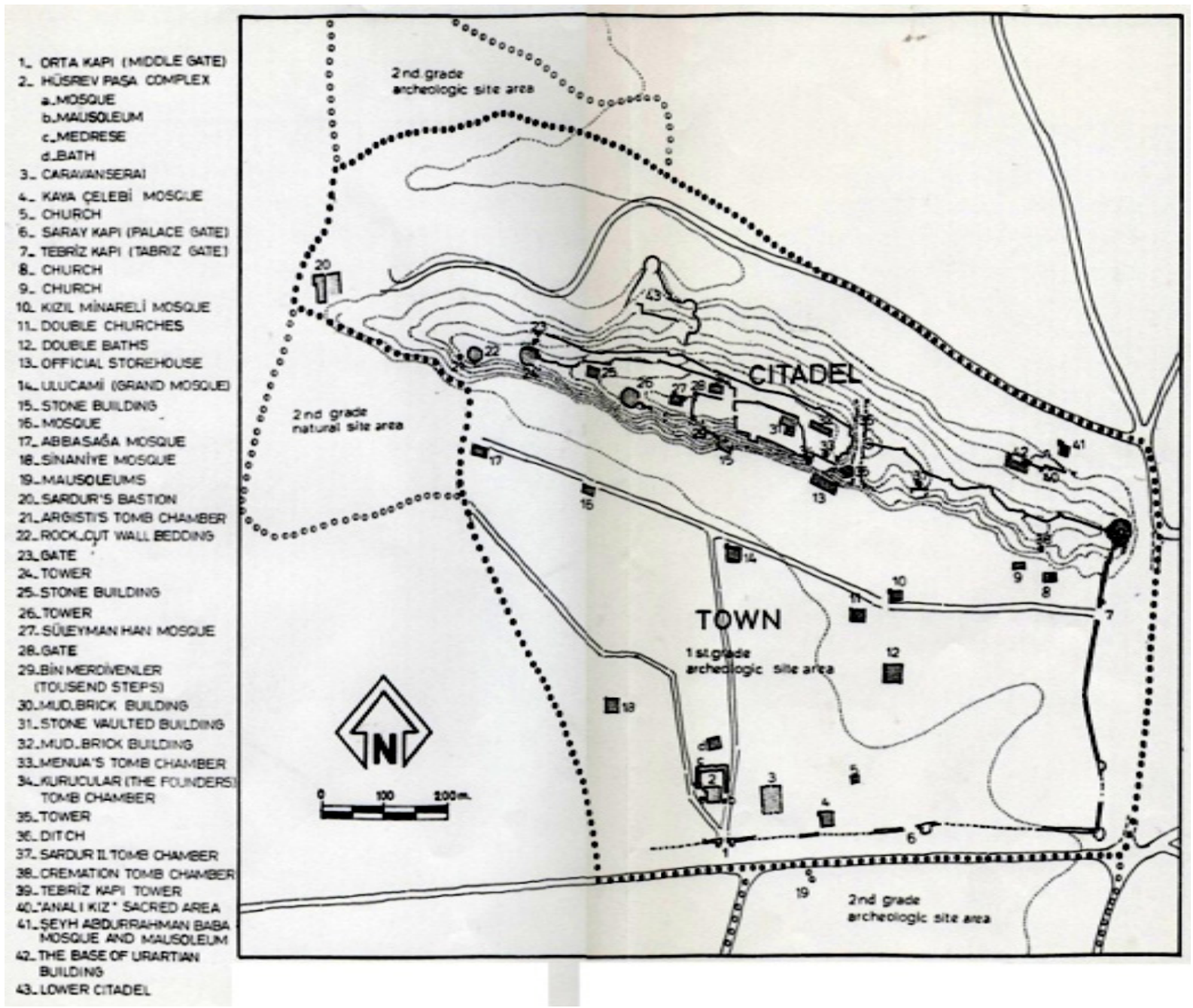

Fig. 4 Main immovable cultural assets of Van Castle and Old Van City (O.Ü. Sirel, 1984). 
In 2005, works incident to realization of the "Tuspa Art City" project were carried out by the governor's office as a proposal for the survival of the castle and the old town. This project, considering the protection of historic buildings, by making them live, as well could not be put into practice like T. Tarhan's Historical National Park project [43].

Conservation Zoning Plans (separately for natural and archaeological protection areas) were made in 2013 due to changing substantially of the archeological sites by narrowing of the boundaries thereof, controlling of natural and archaeological protection areas by different committees and 1993 plan's hindering the building of some constructions legally (including Urartian Museum in particular). Changes of protected areas and conservation zoning plans are indicated in Table 3.

Threats on the historical and natural heritages across the Van region described here in above are also valid for the sampling area. The specific threats to the area are seen as follows.

\subsection{Constructions}

Visual and physical potential damage of heavy structuring on Archaeological and Natural Protection Areas was minimized by the 1993 Conservation Zoning Plan [46]. However, the 2nd and 3rd degree archaeological protection areas were narrowed by the change in boundaries dated Dec. 19, 2002 and number 3053, and the area subject to conservation planning has been narrowed by the 2013 Conservation Zoning Plan made based on these boundaries (Table 3 and Fig. 5). The areas excluded from the "Conservation Zoning Plan" were subjected to conditions of the "General Development Plan" of the city. Some parts of the 3rd degree protection area were opened to structuring as the decision of the Conservation Zoning Plan (residential areas, areas of special projects, museum area, etc.).

\subsection{Problems about Restoration of Historical} Monuments

Applications away from the technical and scientific inspection have been made in the restoration works made on the walls and doors of the Van Castle. The buildings restored in this way have lost their authenticity value significantly. The necessary scientific rigor also has not been shown in restorations and reconstructions of the monumental structures in the Old City Van (such as Hüsrevpaşa Complex and Ortakapi) (Figs. 6 and 7).

\subsection{Problems as to Natural Protection Areas and Usage Pressure}

Problems come from: rising of the lake water; pollution caused by settlements and the industrial activities; debris dumping; interfering the flow of natural water and taking water from the area; the effects of drugs used in agricultural production; illegal hunting and uncontrolled cutting of the reeds; deteriorations in flora and fauna caused by noise and light due to being very close to the city. For example, red and yellow-billed

Table 3 Changes of site areas and conservation zoning plan limits.

\begin{tabular}{|c|c|c|c|}
\hline Sites area & $\begin{array}{l}1979 \text { GEEAYK decree } \\
\text { "High Council of Historic } \\
\text { Monuments and Antiquities" } \\
\text { the decision dated June 8, } 1979 \\
\text { and number A-1673 }\end{array}$ & KAIP-1993 [46] & KAIP-2013 [47] \\
\hline The 1st degree archeological sites & 85.5 ha & 103.0 ha & 101.4 ha \\
\hline The 2nd degree sites area & 35.5 ha & $72.5 \mathrm{ha}$ & 65.2 ha \\
\hline The 3rd degree sites area & 515.0 ha & 336.5 ha & 203.4 ha \\
\hline The 1st degree natural sites & - & 216.9 ha & 216.9 ha \\
\hline Total site area & 636.0 ha & 693.0 ha & 586.9 ha \\
\hline Planning area & - & $1,029.0 \mathrm{ha}$ & $602.0 \mathrm{ha}$ \\
\hline
\end{tabular}



Van in Terms of Cultural, Historical and Natural Values

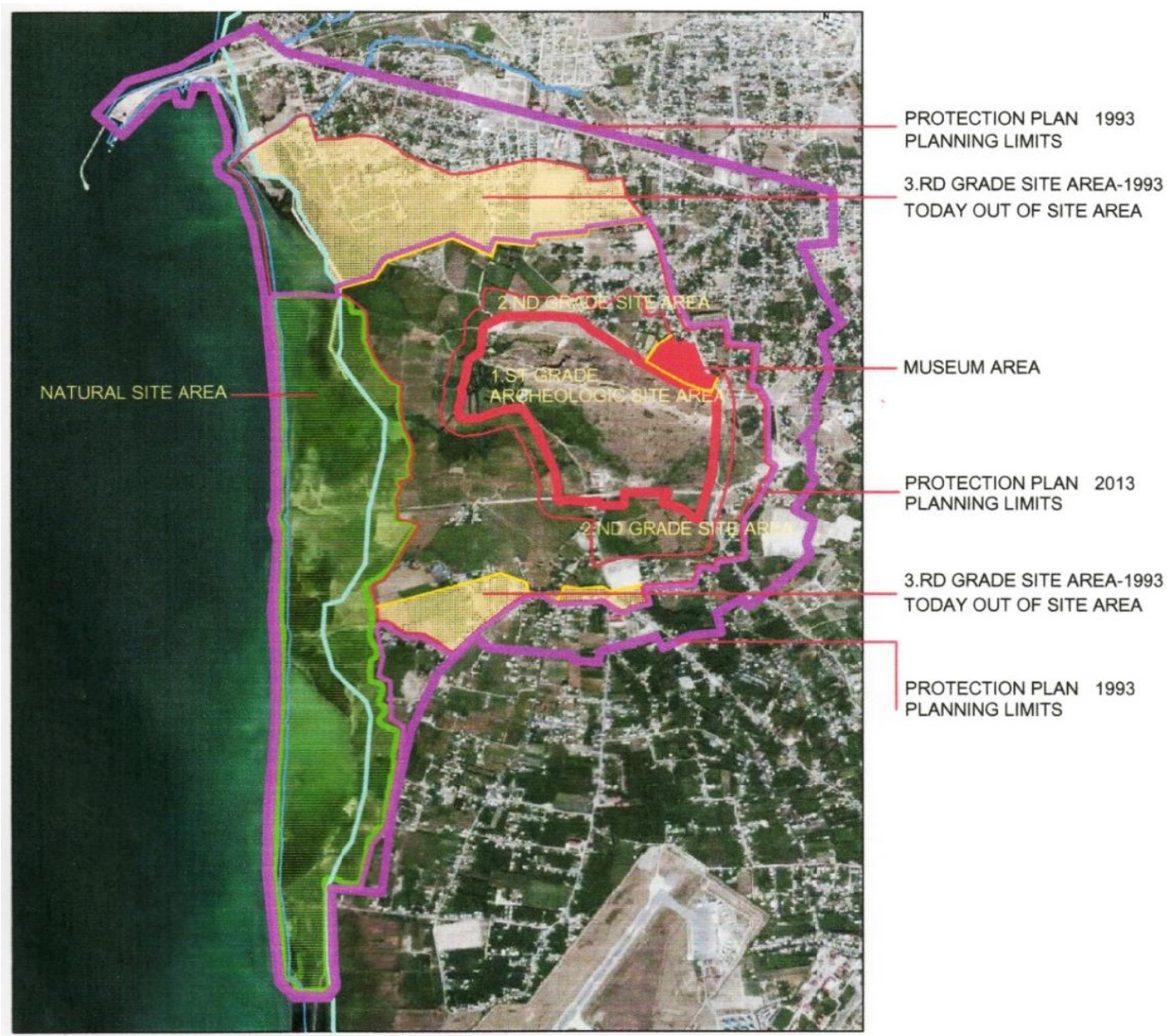

Fig. 5 Site areas and limits of planning area (1993-2013).
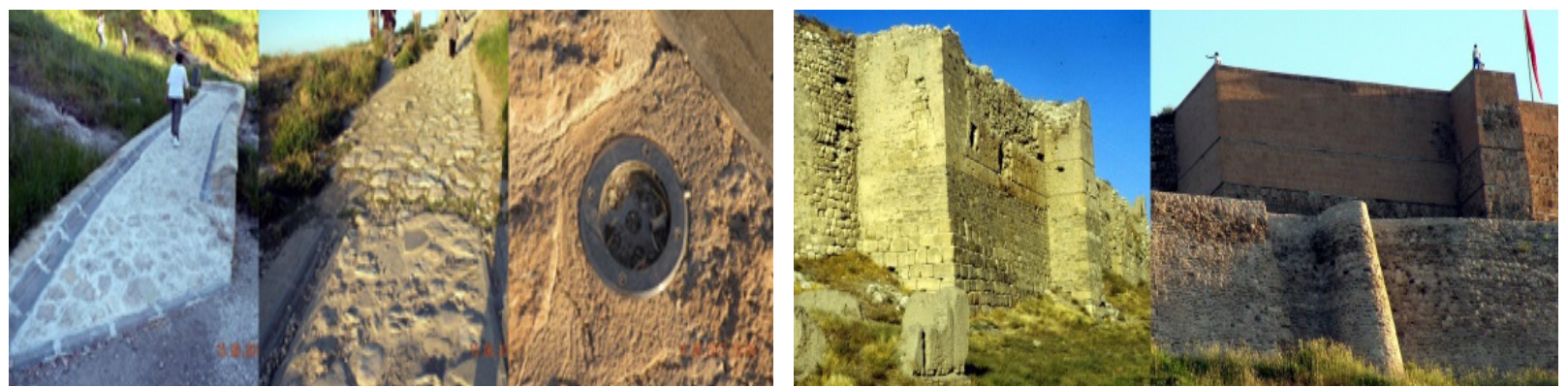

Fig. 6 Restauration problems on the Urartian ramp and walls.
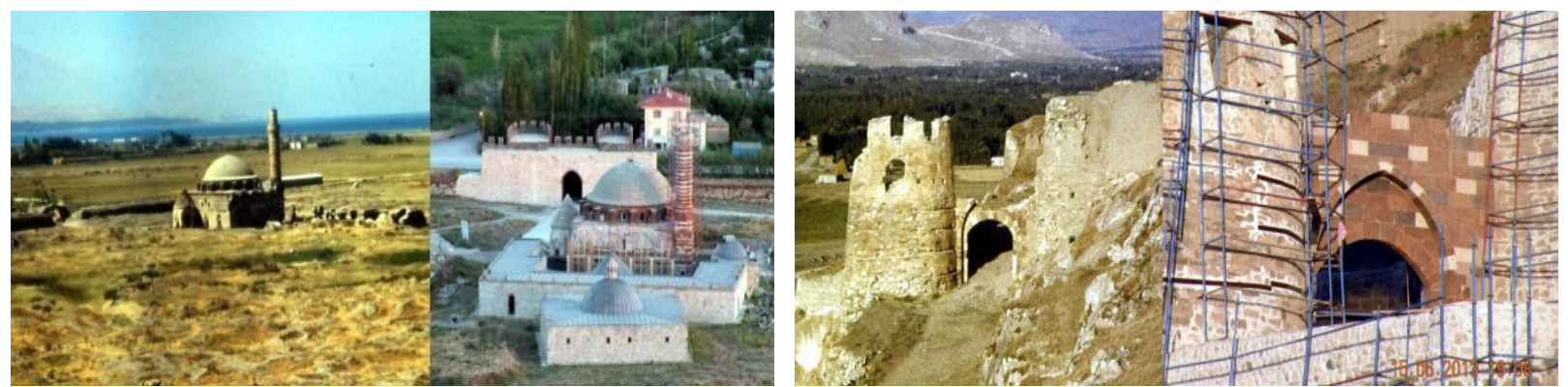

Fig. 7 Some restoration problems. 
crows previously existing in this area cannot be seen anymore; proposal of making a coastal road along the shores of the lake with the 1977 Tourism Master Plan (Van Reeds will disappear in case of realization of this idea proposed without considering the flora and fauna characteristics of Van Lake); Allowing the construction of “..., restaurant, buffet, cafeteria, ...” within the 1st degree natural protection area stated in the notes of "Conservation Implementation Plan for Natural Protection Areas” approved in 2013 (this will cause degeneration of the ecological balance in the area).

\section{Conclusions}

Tourism depends on the presence of heritage resources collected in three groups. These are natural, built and cultural environmental sources. Destination environments have grown rapidly since 1960s all over the world with the widespread application of mass tourism. Bad management of balance of protection-using of the above-mentioned heritage resources in this process has been a critical and major problem environmentally. Observation of devastating effects of tourism on environmental values between the years 1960-1980 has given rise to the concept of sustainable tourism in the 1990s. The first step in this regard has become to recognize the need to draw a new framework for sustainability in tourism. Works have been made on re-drawing of the frame of a planning approach that maximizes environmental and social benefits taking into consideration the bearing capacities of the areas that are subject to tourism. The developed countries have put into action on an array of plans, from local action plans to regional plans and national strategic plans and began to strive managing tourism in accordance with the principles of stability and sustainability.

Tourism has been considered an economic sector in Turkey as in the world. The rapid increase in the request for tourism in Turkey has been evaluated as a success. However, in as much as this rapid process of development in tourism has not been managed by qualified policies and plans, the intensity of use on heritage resources (capacity) has increased. Policies regarding fair use of heritage resources must be established for sustainable tourism. Much as Turkey is being among the top ten countries in terms of visitor attraction in the world, its being in the 46th place in the competitiveness index shows that there is need for developing the current tourism policies on the basis of sustainability and existence of new alternative strategies. In this context, the process must be monitored and evaluated for the success of the "Tourism Action Plan Report" prepared by the Ministry of Culture and Tourism in 2007. Governments, public institutions and organizations, planners, the business world, universities, non-governmental organizations have important tasks and responsibilities for the process to be successful.

The Old Van City and Region which constitutes the sampling area of the study is located in a region which is rich in man-made cultural assets and natural assets. Problems as to use of the heritage values for tourism in the Van city and surroundings which has hosted many civilizations in this period of 2800 years are actually the reflection of the problems within Turkey incident thereto. Narrowing the boundaries of protected areas in the region in particular has increased the pressure of use on the heritage resources subject to tourism. What needs to be done for the realization of sustainable tourism in Van city and the Van region are provided below, accordingly.

\subsection{Recommendations for Sustainability of Values that} Provide Tourist Attractiveness throughout the Van Region

A Tourism Master Plan, which brings forward applicable and realistic goals and which safeguards the sustainability criteria, should be implemented and put into practice in stages.

The wastewater discharge of the settlements around the lake without treatment thereof into the lake should 
be avoided to stop the pollution of Van Lake. In the same way pollution of all the streams flowing to the lake should be avoided.

A complete inventory of historic areas and buildings after the removal must be carried out within a program of excavation and restoration work in the region should be encouraged scientists to do. Excavations should be considered as a means of enhancing the tourist attractiveness of these areas in addition to unearthing the underground works and obtaining scientific data.

Coastal laws must be observed. Accommodation structures for the utilization of the shore should not be high-rise hotels but low-rise resorts that safeguards natural balance.

It should be ensured that hunting ban is severely observed.

Excessive diversification must be avoided to prevent the loss of authenticity of the traditional breakfast of Van and it should be targeted to present regional delicacies with high quality materials and services.

Van region is rich enough not need the "Van Lake Monster" in terms of touristic attractiveness. An effective presentation of actual values must be made in lieu of presentation of dreams and rumor.

It is of great importance to train all the local people in these matters. "Yüzüncü Yil University" should bear important duties in this regard as the university of the region.

Extension of the accommodation periods of tourists in Van will be possible with the utilization and protection of natural and cultural values cited here in above. Following should be made in this context:

- organization of new Van-centered tours should be made;

- the advantages provided by the lake should be utilized effectively (swimming, water sports, and boat tours);

- an effective presentation of the values of the region should be made within the country and abroad.
7.2 Recommendations for Sustainability of Values in Van Castle, Old Van City and the Natural Protection Area

The structuring proposed in "Conservation Implementation Plan" approved in 2013 by the Protection Council by limiting the boundaries will have a negative impact on Van Castle and the Old Van City. As such, Conservation Plan must be revised. In the new planning the natural and archaeological protection areas should be considered with a holistic planning approach including shore of the lake in the north and Akköprü Stream pouring into the sea in this area. Involvement of the people and civil society organizations should be ensured to the planning efforts. This contribution also will contribute to raising awareness of the public on the protection of natural and cultural assets.

The new plan revised in favor of protection of natural environment resources should be implemented, monitored and evaluated. To this end "Area Management" must be established and "Area Management Plan" must be prepared.

Professional guides educated about the region's history, archeology and natural values must be assigned.

Training programs should be organized for changing the understanding which sees Van Castle and the old province of Van as a place of treasure hunting and which sees wetlands as marshes to be dried. The people of the province should be informed and instructed regarding the importance of the protection of historic and scenic areas.

\subsection{Recommendations as to the Historical Values}

Priorities must be determined by completing plan-project works before starting the repair of historic areas and structures.

A rigorous data collection and evaluation should be performed on one hand while emergency and protection works continue on the other hand.

Restoration projects should be prepared by expert 
restorers and in consultation with the scientific establishments constituted of a variety of specialist.

Technical and scientific inspection must be carried out in restoration applications.

\subsection{Recommendations on Natural Protection Areas}

Entries to natural protection areas must be controlled like the entry of the Van Castle.

Local people and managers should be informed as to the importance of the wetlands. Problems that can occur in case of building of the coastal road must be explained. Information as to the legal aspect must also be provided in addition to ecological requirements.

The area should be used for recreation and educational purposes using the advantages of it being close to the province (such as bird watching and controlled excursion routes).

Waters flowing to the area must not be contaminated, and pouring waste water of the surrounding residential units and the facilities to the area without purification must be avoided.

Throwing rubble, excavation debris, etc. to the area must be avoided.

\section{References}

[1] C.R. Goeldner, J.R. Ritchie, Tourism: Principles, Practices and Philosophies, John Willey and Sons Inc., New Jersey, 1990.

[2] Making Tourism more Sustainable-A Guide for Policy Makers, UNEP and UNWTO (United Nations Environment Programme and World Tourism Organization), 2005, pp. 7-12.

[3] ETC and WTO, City Tourism \& Culture: The European Experience, A Report produced for the Research Group of the European Travel Commission and for the World Tourism Organization by LAgroup \& Interarts, Brussels, 2005.

[4] UNWTO/WTTC, The impact of visa facilitation on job creation in the G20 economies, in: The 4th T20 Ministers' Meeting, Mexico, May 15-16, 2012.

[5] UNWTO, Classication Based on the International Monetary Fund (IMF), The Statistical Annex of the IMF World Economic Outlook of April 2012, 2013, p. 177.

[6] D. Glaesser, J. Kester, M. Favılla, S. Carvão, L. Hartantyo, B. Valentın, et al., Visa Facilitation: Stimulating Economic Growth and Development through Tourism,
The travel and tourism competitiveness report, 2013.

[7] B. Stelios, S. Melisidou, Globalisation and sustainable tourism development: A critical review, Journal of Tourism Research, Open Access [Online], 1 (2011) http://www.jotr.eu/ (accessed May 1, 2014).

[8] D.L. Edgell, Managing Sustainable Tourism: A Legacy for the Future, The Haworth Hospitality Press, New York, 2006.

[9] N. Ayas, Sustainable environmental development of tourism, Gazi University, Journal of Faculty of Economics and Management 9 (1) (2007) 59-69. (in Turkish)

[10] L.A. Hardy, S. Beeton, Sustainable tourism or maintainable tourism: Managing resources for more than average outcomes, Journal of Sustainable Tourism 9 (3) (2001) 168-192.

[11] W.D. Ruckelshaus, Toward a sustainable world, Scientific American 261 (1989) 166-175.

[12] R. Gilman, Sustainability, from the 1992 UIA/AIA, "Call for Sustainable Community Solutions”, 1992, http://www.context.org/ICLIB/DEFS/AIADef.htm (accessed June 2, 2014).

[13] C.M. Hui, Sustainable Architecture (Created: Dec 1996), 2002, http://www.arch.hku.hk/research/beer/sustain.htm (accessed Feb. 24, 2014).

[14] W.M. Adams, The future of sustainability: Re-thinking environment and development in the 21 Century, in: The IUCN Renowned Thinkers Meeting, Jan. 29-31, 2006, pp. $1-18$.

[15] J. Saarinen, Traditions of sustainability in tourism studies, Annals of Tourism Research 33 (4) (2006) 1121-1140.

[16] A.S. Travis, Planning for Tourism, Leisure and Sustainability, International Case Studies, International Tourism Consultant, Cambridge, USA, 2011.

[17] R.W. Butler, The concept of a tourist area cycle of evolution: Implications for management of resources, Canadian Geographer 24 (1) (1990) 5-12.

[18] S. Kurt, Tourism Management and Marketing Strategies (Report), Ministry of Culture and Tourism, Aralik, 2009, pp. 36-37. (in Turkish)

[19] A. Sirel, In settlements, where tourism sector is an important part of inhabitants' income, about tourism that is sustainable "without losing values of tourism", in: Famagusta Symposium, Gazimağusa, Oct. 22-28, 1999, pp. 4-5. (in Turkish)

[20] A. Sörensson, Can Tourism Be Sustainable?, Service Experiences from Tourism Destinations in Europe, School of Business and Economics, Åbo Akademi University, Åbo, Finland, 2014, pp. 26-32

[21] Our Common Future, Report of the world commission on environment and development, UN (United Nations), 1987, pp. 11-12.

[22] M. Altinay, K. Hussain, Sustainable tourism development: 
A case study of North Cyprus, International Journal of Contemporary Hospitality Management 17 (3) (2005) 272-280

[23] H. Muller, The thorny path to sustainable tourism development, Journal of Sustainable Tourism 2 (3) (1994) 131-136.

[24] H. Goodwin, A global review on sustainable tourism development with particular reference to the UNWTO indicators for sustainable tourism development, in: UNWTO Conference on Sustainable Tourism Development (Conference Report), Hyderabad, India, Apr. 11, 2013, p. 14.

[25] S. Atabay, Sustainable tourism policies in 21th century, in: 1st International Tourism Symposium, Yildiz Technical University Press Center, Istanbul, 1998, pp. 1-2. (in Turkish)

[26] K. Endresen, Sustainable Tourism and Cultural Heritage: A Review of Development Assistance and Its Potential to Promote Sustainability, New York, 1999, pp. 1-4.

[27] Z. Akınci, Analysis of special interest tourism from sustainable tourism of view, in: Symposium of Tourism and Architecture, Social, Cultural and Physical Developments at Tourism: Problems and Proposals, TMMOB Antalya Şubesi and Akdeniz Üniversitesi, Antalya, 2006, pp. 53-61. (in Turkish)

[28] B. Bramwell, B. Lane, Sustainable tourism: An evolving global approach, Journal of Sustainable Tourism 1 (1) (1993) 6-16.

[29] Guide for Local Authorities on Developing Sustainable Tourism, WTO (World Tourism Organization), Madrid, 1998.

[30] Policity and Practice for Global Tourism (Report), UNWTO (United Nations World Tourism Organization), Madrit, Spain, 2011.

[31] J. Saarinen, Critical sustainability: Setting the limits to growth and responsibility in tourism, Sustainability 6 (2014) 1-17.

[32] A. Ali, An investigation into information and communication technologies-based applications for sustainable tourism development of destinations, Ph.D. Thesis, Queen Margaret University, Edinburgh, 2009.

[33] T. Berno, K. Bricker, Sustainable tourism development: The long road from theory to practice, International Journal of Economic Development 3 (3) (2001) 1-18.

[34] Destination Management Handbook, English Tourist Board and Tourism Management Institute, English Tourism Council, London, 2003, pp. 3-4.

[35] N. Kozak, Basics of Tourism, Anadolu University, Eskişehir, 2012, p. 125. (in Turkish)

[36] G. Emekli, A. İbrahimov, F. Soykan, Geographical approaches to globalization in tourism and turkey, Journal of Ege Geography 15 (2006) 1-16. (in Turkish)
[37] Turkish Industry and Business Association, Sustainable tourism report 2012, İstanbul, 2012, p. 28. (in Turkish)

[38] J. Blanke, T. Chiesa, The travel and tourism competitiveness report 2013, reducing barriers to economic growth and job creation, in: WEF (World Economic Forum), Geneva-Switzerland, 2013, pp. 21-37.

[39] Travel \& Tourism: Economic Impact 2012, WTTC (World Travel and Tourism Council), Cape Verde, London, 2012.

[40] UNWTO (United Nations World Tourism Organisation), Tourism Highlights, 2013, pp. 1-15, www.unwto.org/pub (accessed Apr. 1, 2014).

[41] T.C. Kültür, T. Bakanliği, Republic of Turkey Ministry of Culture and Tourism, Tourism Strategy in Turkey 2023 Action Plan 2007-2013 Report, Ministry of Culture and Tourism Publishment-3085, Ankara, 2007, pp. 1-7. (in Turkish)

[42] F. Aslan, The tourism policy of European union and an evaluation about tourism strategy 2023 of Turkey, The Journal of International Social Research 7 (31) (2014) 427-438.

[43] M.T. Tarhan, Preliminary studies on the historical national park project of the Van castle and old Van city, in: 2nd Gathering about Research Outcome, Ankara, 1985, pp. 179-203. (in Turkish)

[44] V. Sevin, "Urartu", Culture and Art, Turkey is Bank Culture Publishment, Ankara, 1996, p. 17. (in Turkish)

[45] M.T. Tarhan, Preliminary studies of van castle and old van city on the historical national park projects and ideas about this topic, Journal of Archeological and Art History 38 (3) (1988) 21-27. (in Turkish)

[46] O. ÜmitSirel, KAİP-1993, Report of protection plan of Van Castle and vicinity, 1993, p. 30. (in Turkish)

[47] KAİP-2013, Protection plan report about archeological sites around Old Van City and Van Castle, Taha Orhan planning, engineering, constructing energy and tourism Com., 2013. (in Turkish)

[48] O. Çetinkaya, Basin of lake van water sources and fishing options, in: 1st Seafood Symposium in East Anatolian Region, Erzurum, 1993, pp. 71-83. (in Turkish)

[49] O. Belli, Research of Urartian dams and irrigation systems in Van region, 6th Gathering on Research Results, May 23-27, 1988, pp. 313-331. (in Turkish)

[50] Nature Scouts Society-Species Living on Van Swamps and "Rare Bird Area", Threats on Those Species, Risks and Measures, Report on demand of Van municipality, 2006. (in Turkish)

[51] Van Tourism Inventory-1992, Van City Tourism Directorate, 1992. (in Turkish)

[52] A. Uğurlar, Effects of tourism on micro economy and its sustainability case study: Van, Master's Thesis, City and Area Planning, Gazi University Institute of Science and Technology, Ankara, 2006. (in Turkish). 